\title{
Physiological and Biochemical Responses of Semiarid Plants Subjected to Water Stress
}

\author{
Alexandre Bosco de Oliveira ${ }^{1}$, \\ Nara Lídia Mendes Alencar ${ }^{2}$ and Enéas Gomes-Filho ${ }^{2}$ \\ ${ }^{1}$ State University of Piaui, \\ ${ }^{2}$ Federal University of Ceará and \\ National Institute of Science and Technology Salinity/CNPq \\ Brazil
}

\section{Introduction}

Plants are often subjected to periods of soil and atmospheric water deficits during their life cycle. Moreover, the faster-than-predicted change in global climate (Intergovernmental Panel on Climate Change, 2007) and the different available scenarios for climate change suggest an increase in aridity for the semiarid regions of the globe. Together with overpopulation, this will lead to an overexploitation of water resources for agriculture purposes and increased constraints on plant growth and survival and, therefore, on realizing crop yield potential (Chaves et al., 2003; Passioura, 2007).

Water is one of the fundamental resources for the vital processes of vegetation. Plants need to maintain adequate levels of water in their tissues to assure growth and survival and to perform physiological processes, such as photosynthesis and nutrient uptake (Kramer \& Boyer, 1995; Larcher, 1995; Nobel, 1999). In conditions of water deficit, plant cell turgor is reduced, and a series of harmful effects on plant physiology-e.g., reduction of cell growth, cell wall synthesis, protein synthesis, respiration, and sugar accumulation-occur, generating a state of increasing suffering in plants, usually named 'water stress' (Smith \& Griffith, 1993; Lauenroth et al., 1994).

Drought is the most important limiting factor for crop production; it is becoming an increasingly severe problem in many regions of the world. In addition to the complexity of drought itself (Passioura, 2007), plant responses to drought are complex, and different mechanisms are adopted by plants when they encounter drought (Jones, 2004). These mechanisms can include: (i) drought escape by rapid development, which allows plants to finish their cycle before severe water stress; (ii) drought avoidance by, for instance, increasing water uptake and reducing transpiration rate by the reduction of stomatal conductance and leaf area; (iii) drought tolerance by maintaining tissue turgor during water stress via osmotic adjustment, which allows plants to maintain growth under water stress; and (iv) resisting severe stress through survival mechanisms (Izanloo et al., 2008). However, this last mechanism is typically not relevant to agriculture (Tardieu, 2005). The maintenance of high plant water status and plant functions at low plant water potential and the recovery of plant function after water stress are the major physiological processes that contribute to the maintenance of high yield under cyclic drought periods (Blum, 1996). 
Water stress has been identified as a factor that negatively affects the ratio of reproductive to vegetative growth, seed yield and its components (Iannucci \& Martinello, 1998). Many of the changes, which occur in plants during drought stress, represent adaptive responses by which plants cope with water stress. Plants subjected to periods of water stress show an acclimation or hardening and are able to survive subsequent drought periods with less damage compared to plants not previously stressed. The mechanisms developed as survival strategies include tolerance and avoidance of water stress (Zhu et al., 1997).

Generally, stress avoidance involves stomatal closure, hydraulic conductance and root growth patterns. Stress tolerance usually includes osmotic adjustment and changes in tissue elasticity (Jones et al., 1981). Osmotic adjustment (i.e., the lowering of the osmotic potential by net solute accumulation in response to dehydration) aids in the maintenance of turgor at lower water potentials and is considered a beneficial drought tolerance mechanism in both the vegetative and reproductive phases of crop growth (Rascio et al., 1994). The maintenance of turgor above a particular threshold is essential for many physiological processes, such as cell expansion, photosynthesis, gas exchange, enzymatic activities, and continuous growth and maintenance. In addition, the acclimation of plants subjected to drought is also indicated by the accumulation of certain new metabolites associated with structural capabilities to improve plant functions under drought stress (Pinheiro et al., 2001). Understanding how plants respond to drought can play a major role in stabilizing crop performance under water stress conditions and in the protection of natural vegetation. Adequate management techniques and plant genetic breeding are tools for improving resource use efficiency (including water) by plants (Chaves et al., 2009). Thus, using physiological and molecular genetics tools to enhance our understanding of the physiology and genetic control of these mechanisms will assist breeding programs seeking to improve drought resistance in crop plants. Physiological studies will help to establish the precise screening techniques necessary to identify traits related to plant productivity (Izanloo et al., 2008).

Plant responses to drought stress are complex and involve adaptive changes and/or deleterious effects. The decrease in the water potential results in reduced cell growth, root growth and shoot growth and also causes inhibition of cell expansion and reduction in cell wall synthesis (Chaitanya et al., 2003). A relatively mild water potential around $-0.8 \mathrm{MPa}$ reduces the cytokinin content in the leaves of several species (Salisbury \& Ross, 1986). Low leaf water potentials inhibit the activities of the enzymes of the pentose phosphate pathway (Hay \& Walker, 1989). When water stress is reduced from -1.0 to -2.0 MPa, cells become smaller and leaves develop less, resulting in a reduced area for photosynthesis. At these water potentials, ion transport is slowed and may also lead to a decrease in yield (Medrano et al., 2002).

Cell membranes are the primary targets of many plant stresses (Bajji et al., 2002). Osmotic stress induces rapid changes in cell wall conductivity and plasmalemma (Chazen \& Neumann, 1994). The regulation of permeability that occurs during drought stress are accomplished by the opening and closing of water channels formed by membrane polypeptide complexes (Maurel, 1997; Chrispeels et al., 1999) and also by the phase transitions of membrane lipids (Crowe et al., 1992). Water stress affects the regular metabolism of the cell, such as the carbon reduction cycle, light reactions, energy charge and proton pumping, and leads to the production of toxic molecules (Noctor \& Foyer, 1998; Chaitanya et al., 2003). 
Such change(s) in the metabolisms of plants under environmental stress conditions requires an adjustment of metabolic pathways, aimed at achieving a new state of homeostasis, in a process that is usually referred to as acclimation (Mittler 2006; Suzuki \& Mittler, 2006). Several different phases are thought to be involved in acclimation. In the initial stages, the change in the environmental condition is sensed by the plant and activates a network of signaling pathways. In later phases, the signal transduction pathways activated in the first phase trigger the production of different proteins and compounds that restore or achieve a new state of homeostasis (Shulaev et al., 2008).

The intensity, duration and rate of progression of the stress will influence factors that will dictate whether mitigation processes associated with acclimation will or will not occur. Acclimation responses under drought, which indirectly affect photosynthesis, include those related to growth inhibition or leaf shedding that, by restricting water expenditure by source tissues, will help to maintain plant water status and, therefore, plant carbon assimilation. Osmotic compounds that build up in response to a slowly imposed dehydration also have a function in sustaining tissue metabolic activity. Acclimation responses also include synthesis of compatible solutes and adjustments in ion transport. These responses will eventually lead to restoration of cellular homeostasis and, therefore, survival under stress (Chaves et al., 2009). Thus, when plants experience the unfavorable environmental conditions associated with high levels of drought, plant cells protect themselves from the stress of high concentrations of intracellular salts by accumulating a variety of small, organic, electrically neutral molecules that are collectively referred to as compatible solutes or osmoprotectants (Tamura et al., 2003). Compatible solutes are defined as small molecules that are highly soluble in water and are also uniformly neutral with respect to the perturbation of cellular functions, even at high concentrations (Yancy et al., 1982). The properties of compatible solutes allow the maintenance of turgor pressure during water stress, which is an intrinsic feature of major forms of abiotic stress. In addition, some compatible solutes can serve as efficient protective agents by stabilizing the structures and functions of certain macromolecules (Papageorgiou \& Murata, 1995).

\section{Specific examples for semiarid plants under water stress}

\subsection{Seed germination and vigor in water stress conditions}

Light, temperature and water availability are important abiotic factors that determine the germination of dispersed seeds (Baskin \& Baskin, 1998). These factors may be extreme, so their effects can be crucial in the germination and establishment of plants inhabiting arid and semiarid environments (Kigel, 1995). Germination and seedling establishment, due to their dependence on these external factors, are considered to be the most vulnerable stages (Natale et al., 2010). Several desert species are able to germinate at relatively low soil water potential; however, germinability decreases with the reduction in water availability (Kigel, 1995).

In a study with cotton cultivar seeds, it was observed that these seeds are relatively tolerant to water stress induced by PEG-6000. The water stress was most effective in reducing cotton seed viability and vigor at osmotic potentials equal to or more negative than $-0.4 \mathrm{MPa}$ (Meneses et al., 2011). Another interesting example is Sorghum bicolor L., which is recognized by its moderate tolerance to water stress (Tabosa et al., 2002), and is an alternative crop that can be used under water deficit. Oliveira et al. (2010), studying the germination and vigor of sorghum seeds under water and salt stress, observed that salt and water stress negatively 
affected the germination process of these seeds, reducing their vigor. The evaluated genotypes showed different responses to water and salt stress conditions: the CSF 18 sorghum seeds showed higher germination and vigor than did the CSF 20 seeds. With the increase in water deficit, the increase in the number of days for stabilizing the germination was verified. The osmotic potential contributed to the slowest germination, and vigor was more affected than germination (which was more affected in the first counting than in the final germination) (Oliveira et al., 2010).

The germination and seedling establishment of Tamarix ramosissima, which constitutes one of the most successful groups of invasive plants in desert riparian ecosystems in the United States, was assessed under different conditions of water availability by Natale et al. (2010). This species seems to be more sensitive to water deficit than to the presence of salts in the substrate. The tolerance limits for germination reached values of $-0.4 \mathrm{MPa}$ (PEG-6000). The sensitivity of $T$. ramosissima to water deficit was even more evident in the case of vegetative reproduction. Aerial tissue production by cutting was inhibited by an osmotic potential of $0.4 \mathrm{MPa}$, a value fairly common in soils that are considered to have a good level of water availability, such as those in the sub-humid region of Argentina, where Tamarix species have not been reported to grow spontaneously (Natale et al., 2008).

In a study that evaluated the water stress effects on seed germination responses of Cereus jamacaru DC. spp., a cactus widely distributed in Caatinga vegetation, a semiarid ecosystem that characterizes northeastern Brazil (Meiado et al., 2008), low seed germination was observed at a solution concentration of $-0.8 \mathrm{MPa}$ in water stress induced by PEG under white light. However, C. jamacaru seed germinability was reduced by the reduction of water viability, which affected the mean germination time and the synchronization index. Moreover, in this experiment, germination in the -1.0 MPa range was not observed (Meiado et al., 2010). Another study involving a species of cactus widely distributed in northeastern Brazil was performed with Hylocereus setaceus (Salm-Dyck ex DC), whose seeds were subjected to reduced water potentials. In this study, germination was sensitive to decreasing values of $\Psi_{\mathrm{S}}$ in the medium, and both the germinability and the germination rate shifted negatively with the reduction of $\Psi_{\mathrm{s}}$, but the rate of reduction changed with temperature (Simão et al., 2010).

The germination of the semi-deciduous heliophytic tree Caesalpinia peltophoroides, popularly known as sibipiruna, was studied under different conditions of light, temperature and water stress. In this study, low water potential reduced both germinability and the germination rate. Under water stress, the seeds were inhibited by white light mediated by phytochrome (Ferraz-Grande \& Takaki, 2006).

Water stress affected seed germination and seedling vigor of faveira (Clitoria fairchildiana $\mathrm{R}$. Howard, Fabaceae), a widely used tree species in reforestation projects that is recommended for the recovery of degraded areas due to its utility as green manure. Water excess reduced the total amount and the speed of seed germination, whereas the lack of water reduced seedling growth (Silva \& Carvalho, 2008).

\subsection{Growth and productivity analysis of semiarid plants subjected to water stress}

Water deficit is one of the most important environmental stresses affecting agricultural productivity around the world (Hessine et al., 2009). Water availability is undoubtedly the main factor affecting plant growth and development. Moreover, high luminosity, high temperatures and low air relative humidity are further problems plants face in dry lands 
(Chaves et al., 2003; Silva et al., 2010a). Morphological and biochemical changes in plants under water deficit lead to acclimation, subsequent functional damage and the loss of plant parts as water stress becomes more severe (Chaves et al., 2003; Costa e Silva et al., 2004), resulting first in a slower growth rate (acclimation phase). This occurs due to the inhibition of cell expansion and a reduction in carbon assimilation (Costa e Silva et al., 2004). Growth maintenance depends on the turgor pressure for cell expansion and division, which is affected by drought (Taiz \& Zeiger, 2009). Thus, a reduction in growth is considered the principal effect of drought in plants (Larcher, 1995).

Plants capable of surviving and producing under conditions of low water availability are considered drought-tolerant. From an ecophysiological standpoint regarding strategies for plants living in stressed environments, it is not the maximization of productivity that is important, but the establishment of a balance between yield and survival (Larcher, 1995). However, from an agronomic standpoint, yield is the main objective. Plants that stop growth to survive in a stressful environment could be considered tolerant, but such plants produce fewer grains, leaves or fruit, thus reducing their economic worth (DaMatta, 2004). The yields of crop plants under soil and/or atmospheric drought stress will largely depend on the adaptive mechanisms that allow them to maintain growth and high photosynthetic production under prolonged drought conditions (DaMatta, 2007).

Jatropha curcas is a deciduous stem succulent species with a clear drought avoidance strategy in its leaves, a relatively high water use efficiency and most likely a relatively low water footprint (Maes et al., 2009). In a study involving the biomass production and allocation in J. curcas L., Achten et al. (2010) observed that drought treatment significantly influenced growth, biomass allocation, allometry and leaf area. The monitoring of growth and biomass allocation showed that, in optimal conditions, J. curcas grows fast, produces a lot of biomass and achieves a high leaf area compared to other tropical deciduous woody species. At the threshold of drought stress (40\% plant-available water - PAW), J. curcas could still maintain considerable growth and biomass production, without changing the form of its stem and its biomass allocation pattern. Under extreme drought, J. curcas started shedding its leaves and stopped growing. In such a situation, the biomass allocation exhibited a higher investment in its roots. Well and moderately watered Jatropha plants showed medium biomass investment in leaves and low biomass investment in roots, compared to other tropical deciduous woody tree and shrub species (Achten et al., 2010).

In another study of J. curcas, Silva et al. (2010b) observed that water-stressed plants, induced by PEG, suffered higher restrictions in leaf growth compared to salt-stressed plants. In parallel, regarding leaf dry matter reduction, the leaf area decreased by $28 \%(\mathrm{NaCl})$ and $39 \%$ (PEG) in stressed plants compared to the controls. Again, similar to the results for leaf dry matter, PEG- and NaCl-stressed plants showed only a partial recovery in leaf area after 8 days achieving values of approximately $85 \%$ and $79 \%$ compared to the controls, respectively. This partial recovery in leaf area occurred in parallel to the restoration in the leaf dry weight. The comparative analyses between the effects of salt and PEG treatments in terms of variables associated with leaf stress intensity (i.e., membrane integrity, leaf growth and water potential) strongly suggest that the PEG treatment caused more negative effects on the physic nut young plants than did $\mathrm{NaCl}$.

Erythrina velutina Willd., a deciduous plant found in the semiarid region of northeastern Brazil, was subjected to different levels of water stress to evaluate growth parameters and water relationships. In this study, all growth parameters were reduced due to water deficit, 
especially in the plants growth to $25 \%$ of the field capacity, as determined by number of leaves, stem diameter, plant height, leaf area, specific leaf area and dry mass in several organs. Leaf area and root: shoot ratios were not affected. E. velutina seedlings seem to have developed rusticity to overcome intermittent droughts, with no changes in the pattern of dry matter distribution. The maintenance of turgor pressure seems to be more associated with a reduction in the growth ratio than a reduction in leaf water potential (Silva et al., 2010a).

The influence of water stress on grain yield and vegetative growth were evaluated in two cultivars of beans. The Carioca cultivar, an indeterminate Brazilian landrace, appears to be generally stress-tolerant, whereas the Prince cultivar is stress-intolerant. In this study, water stress reduced yield and yield components at both flowering and pod-filling stages. Moreover, seed weight, number of seeds per plant and number of pods per plant and per seed weight were affected (Boutraa \& Sanders, 2001). Water stress during both phenological stages reduced other growth parameters (e.g., the number of trifoliate leaves, stem height, the number of main branches and the number of nodes on the main stem) (Boutraa \& Sanders, 2001).

Water deficit is one of the major factors limiting the production of sugarcane (Saccharum officinarum L.). Silva et al. (2008) investigated the effects of limited water condition on yield components as indicators of drought tolerance in sugarcane. These authors described that under stress, the tolerant control (TCP93-4245) showed higher productivity, stalk number, stalk height and stalk weight than did the susceptible control (TCP87-3388). However, the susceptible control exhibited higher stalk diameter. A linear association was found between productivity and its yield components, but stalk diameter was shown to be fairly unstable among genotypes.

\subsection{Osmoregulation (the participation of organic and inorganic solutes)}

Osmotic stress is a physiological event often associated with excessive water deficit that can reduce plant growth through mechanisms that are not yet fully understood. Osmotic adjustment is a cellular adaptive mechanism vital for stress-tolerant plants, allowing for plants to continue growing in the case of drought (Silva et al., 2010c). It is usually defined as a decrease in the cell sap osmotic potential, resulting from a net increase (discounting the concentration effect due to drought-induced reduction in cell volume) in intracellular solutes rather than from a loss of cell water (Kusaka et al., 2005). This process has been considered as an important physiological adaptation characteristic associated with drought tolerance, and it has drawn much attention during the last years (Hessine et al., 2009). Osmotic adjustment involves the net accumulation of solutes in plant cells in response to falls in water potential in the root medium. As a consequence, the cell's osmotic potential is diminished; this, in turn, attracts water into the cell by tending to maintain turgor pressure (Pérez-Pérez et al., 2009). According to Martinez et al. (2005), compatible solubles, such as sugars, glycerol, proline or glycinebetaine, can also contribute to this process.

The roles of organic and inorganic solutes in the osmotic adjustment of drought-stressed Jatropha curcas plants were evaluated by Silva et al. (2010c). Regarding inorganic solutes, these authors observed that $\mathrm{K}^{+}$had greater quantitative participation in osmotic adjustment, followed by $\mathrm{Na}^{+}$and $\mathrm{Cl}^{-}$. Regarding the organic solutes, the total soluble sugars had the highest contribution to osmotic adjustment, mainly in the most severe cases of water stress. Young J. curcas plants exhibited osmotic adjustment in roots and leaves in response to 
drought stress that was linked with mechanisms to prevent water loss by transpiration by means of the participation of inorganic and organic solutes and stomatal closure (Silva et al., 2010c).

Organic solute production in four umbu tree (Spondias tuberosa) genotypes under intermittent drought was evaluated by Silva et al. (2009). The authors concluded that umbu trees presented isohydric behavior during intermittent drought, maintaining high leaf water potential and great variability in the production of organic solutes with marked differences among the genotypes. The high values of water potential and the variability in the organic solutes studied suggest that the storage of water in the xylopodium associated with stomatal closure is responsible for maintaining turgor in the leaves of the umbu tree genotypes; additionally, solute accumulation as a drought-tolerance indicator was not evident in umbu plants.

Osmotically active solutes in cassava leaves during water stress and the contribution of solutes to osmotic adjustment were investigated by Alves \& Setter (2003). They observed that $\mathrm{K}^{+}$inorganic solute was the major contributor to total osmolytes in both mature and expanding leaves, accounting for approximately $60 \%$ of the osmotic potential. The concentration of K-salts increased in response to water stress and was positively correlated with the extent of OA. In contrast, total sugars (sucrose + glucose + fructose) decreased during water deficit, exhibiting a negative correlation with OA. Although the concentration of proline in mature leaves increased in response to water stress, its contribution to the total change in osmotic potential was insignificant (Alves \& Setter, 2003).

Osmotic adjustment as a tolerance mechanism to water stress in young jackfruit and sugar apple trees was evaluated by Rodrigues et al. (2010). They observed an accumulation of solute sugars, followed by an increase in protein and amino acid concentrations in waterstressed leaves. They also observed that both evaluated species had a high tolerance to the stressful climatic conditions that occur in the semiarid region of northeastern Brazil. Moreover, jackfruit proved to be more tolerant than sugar apple due to the maintenance of a higher leaf water potential under water deficit.

In a study with cowpea (Vigna unguiculata) subjected to water stress and recovery treatment, Souza et al. (2004) showed that carbohydrate metabolic changes revealed an accumulation of soluble sugars in water-stressed leaves, which also persisted for one day after re-watering. This finding suggests a transient end-product inhibition of photosynthesis, contributing to a minor non-stomatal limitation during stress and the initial phase of recovery. Moreover, increases in proline levels were small, and their onset was delayed after stress imposition; thus, their increase may be a consequence instead of a stress-induced beneficial response.

The effect of salinity and PEG-induced water stress on water status, gas exchange, and solute accumulation in Ipomoea pes-caprae was evaluated by Sucre \& Suárez (2011). They observed that under saline conditions, plants accumulated higher $\mathrm{Na}^{+}$concentrations; the accumulation increased with increasing $\mathrm{NaCl}$ concentration. However, the leaf $\mathrm{Na}^{+}$ concentration of plants growing under PEG-induced water stress was higher than expected. Regarding proline, an increase of $-1.0 \mathrm{MPa}$ was observed by the addition of $\mathrm{NaCl}$ or PEG compared to control plants. Proline accumulation is considered the first response of plants exposed to salt stress and water-deficit stress to reduce leaf osmotic potential; the kinetics of accumulation of this solute depend on the intensity and duration of the stress (Ashraf \& Foolad, 2007). 
The impact of water shortage on leaf osmotic potential and proline accumulation was evaluated in young plants of two Brazilian green dwarf (BGD) coconut ecotypes. Green dwarf coconut palms exhibited low osmotic adjustment (from 0.05 to $0.24 \mathrm{MPa}$ ) and a significant accumulation of proline (1.5 to 2.1 times more than the control) in leaflets in response to water deficit. Considering the growth reduction observed in both ecotypes, proline was not associated to with osmoregulation (Gomes et al., 2010).

The impact of salinity and water stress was analyzed in the xero-halophyte Atriplex ortensis, which is a $\mathrm{C}_{3}$ species well adapted to salt and drought conditions. $\mathrm{Na}^{+}$accumulated in response to drought and salinity conditions, suggesting that this element could play a physiological role in the stress response of this xero-halophyte species. However, $\mathrm{K}^{+}, \mathrm{Ca}^{2+}$ and $\mathrm{Mg}^{2+}$ decreased in response to water and salt stress. $\mathrm{Cl}^{-}$concentration increased in response to salt stress in all tissues, but water stress had no impact on this parameter (Kachout et al., 2011).

Regarding osmoregulation in the coconut palm, proline's contribution to the overall osmotic adjustment in ecotypes of BGD was recently shown to be low (Gomes et al., 2006; Gomes \& Prado, 2007) because: (1) proline concentration was reduced to control levels upon rewatering, whereas osmotic potential did not increase and even decreased in re-watered plants; and (2) the patterns of the two coconut ecotypes evaluated for proline accumulation did not reflect their relative behaviors in terms of osmotic adjustment. Indeed, chloride plays important functions in the water balance of coconut palms. First, $\mathrm{Cl}^{-}$is important for regulating stomatal apertures in coordinated water flow between six neighboring cells (two guard cells and four subsidiary cells) of the coconut stomatal apparatus. During stomatal pore opening, $\mathrm{K}^{+}$and $\mathrm{Cl}^{-}$ions flow from the subsidiary cell to the guard cell. This movement leads to decreases in (water potential) $\Psi_{W}$ of the guard cell and, at the same time, increases $\Psi_{\mathrm{W}}$ of subsidiary cells, driving water flow from the subsidiary to the guard cells (Braconnier \& d’Auzac, 1990).

\subsection{Water relations in semiarid plants}

Water relations in Caatinga trees were evaluated by Dombroski et al. (2011). The species studied were classified into four groups. (I), Mimosa caesalpiniifolia had low leaf water potential $\left(\Psi_{\mathrm{W}}\right)$ at predawn and no significant decrease at midday. Stomatal conductance (gs) analyses indicated that plants had reached their lowest $\Psi_{\mathrm{W}}$. (II), Caesalpinia pyramidalis and Auxemma oncocalyx had low $\Psi_{\mathrm{W}}$ at predawn and significant decreases at midday. For these species, the recuperation of their water statuses at night may have been sufficient for maintaining open stomata during the day. (III), Caesalpinia ferrea and Calliandra spinosa had relatively high $\Psi_{\mathrm{W}}$ at predawn and significant decreases at midday. These species might maintain their water statuses similar to individuals in group II, but they might also have deeper root systems. (IV), Tabebuia caraiba had the highest $\Psi_{\mathrm{W}}$ at predawn and no significant decrease at midday, possibly indicating a combination of good stomatal control of water loss and a deeper root system (Dombroski et al., 2011).

Leaf water relations induced by $\mathrm{NaCl}$ and PEG-6000 were assessed in Ipomoea pes-caprae; the decrease in the nutrient solution water potential $\left(\Psi_{\text {sol }}\right)$ was initially stressful and caused turgor loss Brazilian landrace, but $2 \mathrm{~d}$ after the beginning of the experiment, the plants that

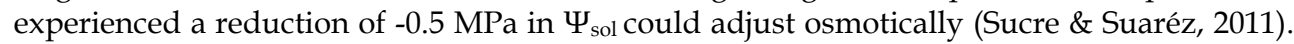
However, under high salinity (HS) and water deficit (HW) stress, the osmotic adjustment was delayed, with a consequent turgor loss during the first $16 \mathrm{~d}$ of treatment. During this 
period in HS and HW, ion delivery and/or synthesis of organic solutes were not enough to achieve the osmotic adjustment necessary for turgor maintenance (Lacerda et al., 2003; Akhiyarova et al., 2005). Subsequently, the resumption of the soil-plant water potential gradient may take place due to the accumulation of inorganic and/or organic solutes in the vacuole, allowing water uptake and enhancing turgor-dependent processes (Akhiyarova et al., 2005).

Water relations evaluated in four umbu tree (Spondia tuberosa) genotypes under intermittent drought showed high leaf water potential (Silva et al., 2009). Significant differences in leaf water potential $\left(\Psi_{\mathrm{W}}\right)$ were observed among the genotypes. GBU 68 showed the highest value of $\Psi_{\mathrm{w}}$, while GBU 50 showed the lowest. Genotypes GBU 44 and GBU 50 showed significantly reduced Brazilian landrace $\Psi_{\mathrm{W}}$ at 8:00 am, while control plants were reduced at 12:00 am (Silva et al., 2009). Recent studies have demonstrated that the water balance of the umbu tree under drought conditions should be maintained through the utilization of the water storage in the roots and low transpiration rates (Lima-Filho, 2001, 2004).

\subsection{Photosynthetic and gas exchange}

The ecophysiology parameters of four Brazilian Atlantic Forest under drought were evaluated by Souza et al. (2010). A water deficit induced by 7 days of irrigation suspension reduced the $\Psi_{\mathrm{w}}$ in all the species studied, except for $C$. zeylancium. This finding was not accompanied by the rates of stomatal conductance $(g s)$, net photosynthesis $(A)$, transpiration $(E)$ and intrinsic water use efficiency (IWUE), except for B. guianensis, which exhibited an $A$ rate of zero. The gas exchange values obtained tended to be lower in plants under stress; however, T. guianensis plants under drought exhibited a high value for $g s$ and $A$. No significant differences were observed for $E$ and IWUE, except for B. guianensis, which showed high $g s$ and $E$ values with a low $A$ rate; thus, the IWUE for this species was the lowest determined (Souza et al., 2010).

The processes involved in the susceptibility of sugarcane plants to water deficit were evaluated in drought-tolerant and drought-sensitive cultivars. The water deficit affected the photosynthetic apparatus of all the plants in different ways within and between cultivars. Photosynthetic rates and stomatal conductances decreased significantly in all cultivars subjected to water deficit Graça et al. (2010). In control tolerant cultivar plants (SP83-2847 and CTC15), the photosynthetic rate was higher than in the sensitive cultivar (SP86-155) (Graça et al., 2010).

The function of the photosynthetic apparatus of cotton (Gossypium hirsutum) grown during the onset of water limitation was studied by gas-exchange and chlorophyll fluorescence. The onset of drought stress caused an increase in the operating quantum efficiency of PSII photochemistry, which indicated increased photorespiration, as photosynthesis was hardly affected by water limitation. The increase in PSII was caused by an increase in the efficiency of open PSII reaction centers $\left(\mathrm{Fv}_{0} / \mathrm{Fm}_{0}\right)$ and by a decrease in basal non-photochemical quenching. The increased rate of photorespiration in plants during the onset of drought stress can be seen as an acclimation process to avoid an over-excitation of PSII under more severe drought conditions (Massaci et al., 2008).

The responses of photosynthetic gas exchange and chlorophyll fluorescence were studied in the cowpea (Vigna unguiculata) during water stress and recovery. The reductions in $\mathrm{CO}_{2}$ assimilation rates in water-stressed cowpea plants were largely dependent on stomatal closure, which decreased available internal $\mathrm{CO}_{2}$ and restricted water loss through 
transpiration. This response seemed to be effective in preventing large decreases in leaf water potential; thus, it appeared to be the basis for dehydration avoidance in the cowpea (Souza et al., 2004).

In the coconut palm, the drought-induced photosynthetic reductions were initially attributable to limited $\mathrm{CO}_{2}$ diffusion from the atmosphere to the intercellular spaces as a result of stomatal closure (Reppellin et al., 1997). Non-stomatal factors have been shown to contribute to the reduction in photosynthesis, both during a period of severe water deficit and during the recovery phase after resuming irrigation (Gomes, 2006; Gomes et al., 2007). Gomes et al. (2007) used net photosynthesis (NP) and internal $\mathrm{CO}_{2}$ concentration (Ci) to show drought-induced non-stomatal limitation to NP in dwarf coconut, as indicated by reductions in $\mathrm{CO}_{2}$-saturated and carboxylation efficiency.

$\mathrm{NaCl}$ and PEG stress were able to induce significant and reversible alterations in the physiological stress indicators associated with water relations, growth and leaf gas exchange, but they were unable to cause any changes in the photochemical activity of young J. curcas plants (Silva et al., 2010b). Both treatments caused similar impairments of the $\mathrm{CO}_{2}$ assimilation rate, but the PEG-stressed plants showed higher restriction in stomatal conductance and transpiration. Although both stresses caused significant decreases in leaf chlorophyll content, photochemical activity was not affected (Silva et al., 2010b).

\section{Conclusion}

The physiological and biochemical changes that occur in semiarid plants subjected to water stress represent adaptive responses by which plants cope with the water deficit. Such species, growing under the low water content that predominates in the soils of these regions, demonstrate an acclimation to this abiotic stress and are able to survive subsequent drought periods with less damage compared to plants from other regions.

\section{Acknowledgment}

The authors would like to thank National Council of Research and Development (CNPq, Brazil) for the fellowships and financial support. The authors would like to thank National Institute of Science and Technology Salinity (CNPq/MCT/Brazil) for the fellowships and financial support.

\section{References}

Achten, W.M.J.; Maes, W.H.; Reubens, B.; Mathijs, E.; Singh, V.P.; Verchot, L.; Muys, B. (2 01 $0)$. Biomass production and allocation in Jatropha curcas L. seedlings under different levels of drought stress. Biomass and Bioenergy, Vol.34, No.5, (May 2010) pp.667676, ISSN 0961-9534

Akhiyarova, G.R.; Sabirzhanova, I.B.; Veselov, D.S.; Frike, V. (2005). Participation of plant hormones in growth resumption of wheat shoots following short-term $\mathrm{NaCl}$ treatment. Russian Journal Plant Physiology. Vol.52, No.6, (May 2005), pp.788-792, ISSN 1021- 4437

Alves, A.A.C.; Setter, T.L. (2004). Abscisic acid accumulation and osmotic adjustment in cassava under water deficit. Environmental and Experimental Botany, Vol.51, No.3, (November 2004), pp.259-271, ISSN 0098-8472 
Ashraf, M.; Foolad, M.R. (2007). Roles of glycine betaine and proline in improving plant abiotic stress resistance. Environmental Experimental Botany, Vol.59, No.2, (March 2007), pp.207-216, ISSN 0098-8472

Bajji, M.; Kinet, J.M.; Luts, S. (2002). The use of electrolyte leakage method for assessing cell membrane stability as a water stress tolerance test in durum wheat. Plant Growth Regulation, Vol.36, No.1, (December 2001), pp.61-70, ISSN 1435-8107Bajji, M.; Kinet, J.M.; Luts, S. (2002). The use of electrolyte leakage method for assessing cell membrane stability as a water stress tolerance test in durum wheat. Plant Growth Regulation, Vol.36, No.1, (December 2001), pp.61-70, ISSN 1435-8107

Baskin, C.C.; Baskin, J.M. (1998). Seeds: ecology, biogeography and evolution of dormancy and germination. Academic Press, ISBN 0-12-080260-0, San Diego

Blum, A. (1996). Crop responses to drought and the interpretation of adaptation. Plant Growth Regulation, Vol.20, No.2, (February 1996), pp.135-148, ISSN 1435-8107

Boutraa, T.; Sanders, F.E. (2001). Influence of water stress on grain yield and vegetative growth of two cultivars of bean (Phaseolus vulgaris L.) Journal of Agronomy \& Crop Science, Vol.187, No. 4, (August 2001), pp.251-257, ISSN 0931-2250

Braconnier, S.; d'Auzac J (1990). Chloride and stomatal conductance in coconut. Plant Physiology and Biochemsitry, Vol. 28, No.1 (April 1990), pp.105-111, ISSN: 0981-9428

Chaitanya, K.Y.; Sundar, D.; Jutur, P.P.; Ramachandra Reddy, A. (2003). Water stress effects on photosynthesis in different mulberry cultivars. Plant Growth Regulation, Vol.40, No.1, (May 2003), pp.75-80, ISSN 1435-8107

Chaves, M.M.; Flexas, J.; Pinheiro, C. (2009). Photosynthesis under drought and salt stress: regulation mechanisms from whole plant to cell. Annals of Botany, Vol.103, No.4, (April 2009), pp. 551-560, ISSN 1095-8290

Chaves, M.M.; Maroco, J.P.; Pereira, J.S. (2003). Understanding plant responses to drought from genes to the whole plant. Functional Plant Biology, Vol.30, No.3, (March 2003), pp. 239-264, ISSN 1445-4408

Chazen, O., Neumann, P.M. (1994). Hydraulic signals from the rots and rapid cell wall hardening in growing maize (Zea mays L.) leaves are primary responses to polyethylene glycol induced water deficits. Plant Physiology, Vol.104, No.4, (April 1994), pp.1385-1392, ISSN 1532-2548

Chrispeels, M.J.; Crawford, N.M.; Schroeder, J.I. (1999). Proteins for transport of water and mineral nutrients across the membranes of plant cells. Plant Cell, Vol.11, No.4, (April 1999), pp.661-676, ISSN 1531-298X

Costa e Silva, F.; Shvaleva, A.; Maroco, J.P.; Almeida, M.H.; Chaves, M.M.; Pereira, J.S. (2004). Responses to water stress in two Eucalyptus globulus clones differing in drought tolerance. Tree Physiology, Vol. 24, No. 10, (August 2004), pp. 1165-1172, ISSN 0829-318X

Crowe, J.H.; Hoekstra, F.A.; Crowe, L.M. (1992). Anhydrobiosis. Annual Review of Plant Physiology and Plant Molecular Biology, Vol.54, No.1, (January 1992), pp.570-599, ISSN 0066-4294

DaMatta, F.M. (2004). Exploring drought tolerance in coffee: a physiological approach with some insights for plant breeding. Brazilian Journal of Plant Physiol, Vol.16, No.1, (January/April 2004), pp.1-6, ISSN 16770420 
DaMatta, F.M. (2007). Ecophysiology of tropical tree crops: an introduction. Brazilian Journal of Plant Physiology, Vol.19, No.4, (October/December 2007), pp.239-244, ISSN 16770420

Dombroski, J.L.D.; Praxedes, S.C.; Freitas, R.M.O.; Pontes, F.M. (2011). Water relations of Caatinga trees in the dry season. South African Journal of Botany, Vol.77, No.2, (April 2011), pp.430-434, ISSN 0254-6299

Ferraz-Grande, F.G.A.; Takaki, M. 2006. Efeitos da luz, temperatura e estresse de água na germinação de sementes de Caesalpinia peltophoroids Benth. (Caesalpinoidea). Bragantia, Vol.65, No.1, pp.37-42,

Gomes, F.P.; Oliva, M.A.; Mielke, M.S.; Almeida, A-AF.; Leite, H.G. (2006). Photosynthetic irradiance-response in leaves of dwarf coconut palm (Cocos nucifera L. 'nana', Arecaceae): Comparison of three models. Scientia Horticulturae, Vol.109, No.1, (June 2006), pp.101-105, ISSN 0304-4238

Gomes, F.P.; Prado, C.H.B.A. (2007). Ecophysiology of coconut palm under water stress. Brazilian Journal of Plant Physiology, Vol.19, No.4, (October/December, 2007), pp.377-391, ISSN 1677-0420

Gomes, F.P.; Olivab, M.A.; Mielkea, M.S.; Almeidaa, A.A.F.; Aquinob, L.A. (2010). Osmotic adjustment, proline accumulation and cell membrane stability in leaves of Cocos nucifera submitted to drought stress. Scientia Horticulturae, Vol:126, No.3, (September 2010), pp.379-384, ISSN 0304-4238

Graça, J.P.; Rodrigues, F.A.; Farias, J.R.B.; Oliveira, M.C.N.; Hoffmann-Campo, C.B.; Zingaretti, S.M. (2010). Physiological parameters in sugarcane cultivars submitted to water stress. Brazilian Journal of Plant Physiology, Vol.22, No.3, (October 2010), pp. 189-197, ISSN 1677-0420

Hay, K.M.H.; Walker, A.J. (1989). Environmental effects on photosynthesis: water stress, In: An introduction to the physiology of crop yield. Photosynthesis efficiency: photosynthesis and respiration, Hay, K.M.H.; Walker, A.J. (Eds.), pp. 68-76, Longman Scientific and Technical, ISBN 978-14051-0859-1, Wiley, New York

Hessine, K.; Martínez, J.P.; Gandour, M.; Albouchi, A.; Soltani, A.; Abdelly, C. (2009). Effect of water stress on growth, osmotic adjustment, cell wall elasticity and water-use efficiency in Spartina alterniflora. Environmental and Experimental Botany, Vol.67, No. 2, (December 2009), pp. 312-319, ISSN 0098-8472

Iannucci, A.; Mattinello, P. (1998). Analysis of seed yield and yield components in four Mediterranean annual clovers. Field Crops Research, Vol.55, No.3, (February 1998), pp.235-243, ISSN 0378-4290

Intergovernmental Panel on Climate Change (2007). http://www.ipcc.ch. Accessed 25 October 2007

Izanloo, A.; Condon, A.G.; Langridge, P.; Tester, M.; Schnurbusch, T. (2008). Different mechanisms of adaptation to cyclic water stress in two South Australian bread wheat cultivars. Journal of Experimental Botany, Vol. 59, No. 12, (August 2008), pp. 3327-3346, ISSN 1460-2431

Jones, H. (2004). What is water use efficiency?, In: Water use efficiency in plant biology, Bacon, M.A. (Ed.), pp. 27-41, Wiley-Blackwell, ISBN 978-1-4051-1434-9, Oxford

Jones, M.M.; Turner, N.C.; Osmond, C.B. (1981). Mechanisms of drought resistance. In: The physiology and biochemistry of drought resistance in plants, Paleg, L.G.; Aspinall, D. (Eds.), pp. 20-35, Academic Press, ISBN 0-12-544380-3, Sydney 
Kachout, S.S.; Mansoura, A.B.; Hamza, K.J.; Leclerc, J.C.; Rejeb, M.N.; Ouergui, Z. (2011). Leaf-water relations and ion concentrations of the halophyte Atriplex hortensis in response to salinity and water stress. Acta Physiologia Plantarum, Vol.33, No.2, (March 2011), pp.335-342, ISSN: 1861-1664

Kigel, J. Seed germination in arid and semiarid regions. (1995). Seed development and germination. Kigel, J.; Galili, G (Eds), p. 645-699, Marcel Dekker, Inc., ISBN 0-82479229, New York

Kramer, P.J.; Boyer, J.S. (1995). Water Relations of Plants and Soils. Academic Press, ISBN 0-12425060-2, San Diego

Kusaka, M.; Lalusin, A.G.; Fujimura, T. 2005. The maintenance of growth and turgor in pearl millet (Pennisetum glaucum [L.] Leeke) cultivars with different root structures and osmo-regulation under drought stress. Plant Science, Vol. 168, pp. 1-14.

Lacerda, C.F.; Cambraia, J.; Oliva, M.A.; Ruiz, H.A.; Prisco, J.T. (2003). Solute accumulation and distribution during shoot and leaf development in two Sorghum genotypes under salt stress. Environmental Experimental Botany, Vol.49, No.2, (April 2003), pp.107-120, ISSN 0098-8472

Larcher, W. (1995). Physiological Plant Ecology. Springer, ISBN 9-78-354043516-7, Berlin

Lauenroth, W.K.; Sala, O.E.; Coffin, D.P.; Kirchner, T.B. (1994). The importance of soil-water in the recruitment of Bouteloua-Gracilis in the shortgrass steppe. Ecological Applications, Vol.4, No.4, (April 1994), pp.741-749, ISSN 1051-0761

Lima-Filho, J.M.P. (2001). Internal water relations of the umbu tree under semi-arid conditions. Revista Brasileira de Fruticultura, Vol. 23, No. 3, (December 2001), pp. 518 -571, ISSN 0100-2945

Lima-Filho, J.M.P. (2004). Gas exchange of the umbu tree under semi arid conditions. Revista Brasileira de Fruticultura, Vol.26, No.2, (August 2004), pp.206-208, ISSN 0100-2945

Maes, M.H.; Achten, W.M.J.; Reubens, B.; Samson, R.; Muys, B. (2009). Plant-water relationships and growth strategies of Jatropha curcas L. saplings under different levels of drought stress. Journal of Arid Environments, Vol.73, No.10, (October 2009), pp.877-84, ISSN 0140-1963

Martinez, J.P.; Kinet, J.M.; Bajji, M. ; Lutts, S. (2005). NaCl alleviates polyethylene glycol induced water stress in the halophyte species Atriplex halimus L. Journal Experimental Botany, Vol.56, No.419, (September 2005), pp.2421-2431, ISSN 00220957

Maurel, C. (1997). Aquaporins and water permeability of plant membranes. Annual Review of Plant Physiology and Plant Molecular Biology, Vol.48, No.1, (June 1997), pp.399-429, ISSN 0066-4294

Massaci, A.; Nabiev, S.M.; Pietrosant, L.; Nematov, S.K.; Chernikova, T.N.; Thor, K.; Leipner, J. (2008). Response of the photosynthetic apparatus of cotton (Gossypium hirsutum) to the onset of drought stress under field conditions studied by gasexchange analysis and chlorophyll fluorescence imaging. Plant Physiology and Biochemistry, Vol.46, No.2, (February 2008), pp.189-195, ISSN: 0981-9428

Medrano, H.; Escalona, J.M.; Bota, J.; Gulías, J.; Flexas, J. (2002). Regulation of photosynthesis of C3 plants in response to progressive drought: stomatal conductance as a reference parameter. Annals of Botany, Vol.89, No.7, (June 2002), pp.895-905, ISSN 0305-7364 
Meiado, M.V.; Albuquerque, L.S.C.; Rocha, E.M.; Rójas-Aréchiga, M.; Leal, I.R. (2010). Seed germination responses of Cereus jamacaru DC. ssp. jamacaru (Cactaceae) to environmental factors. Plant Species Biology, Vol.25, No.2, (May 2010), pp.120-128, ISSN 0913-557X

Meiado, M.V.; Rocha E.A.; Rojas-Aréchiga, M.; Leal, I. R. (2008). Comunidad de cactus en la Caatinga: ¿qué influencia la dinámica de semillas en el ambiente semiárido? Boletín De La Sociedad Latinoamericana Y Del Caribe De Cactáceas Y Otras Suculentas. Vol.5, No.3, (September/December 2008), pp.4-6, ISSN 1856-4569

Meneses, C.H.S.G.; Bruno, R.L.A.; Fernandes, P.D.; Pereira, W.E.; Lima, L.H.G.M; Lima, M.M.A,; Vidal, M.S. (2011). Germination of cotton cultivar seeds under water stress induced by polyethyleneglycol-6000. Scientia Agricola, Vol.68, No.2, (March/April 2001). pp.131-138, ISSN 0103-9016

Mittler, R. (2006). Abiotic stress, the field environment and stress combination. Trends in Plant Science, Vol.11, No.1, (January 2006), pp.11-19, ISSN 1360-1385

Natale, E.; Zalba, S.M.; Oggero, A.; Reinoso, H. (2010). Establishment of Tamarix ramosissima under different conditions of salinity and water availability: Implications for its management as an invasive species. Journal of Arid Environments, Vol.74, No. 11, (November 2010), pp. 1399-1407, ISSN 0140-1963

Natale, E.; Gaskin, J.; Zalba, S.M.; Ceballos, M.; Reinoso, H. (2008). Species of the genus Tamarix (tamarisk) invading natural and semi-natural environments in Argentina. Boletín de la Sociedad Argentina de Botánica, Vol.43, No.1-2, (January/June 2008), pp. 137-145, ISSN 0373-580X

Nobel, P.S. (1999). Physiochemical and Environmental Plant Physiology. Academic Press, ISBN 978-0-12-520026-4, San Diego

Noctor, G.; Foyer, C.H. (1998). Ascorbate and glutathione: keeping active oxygen under control. Annual Review of Plant Physiology and Plant Molecular Biology, Vol.49, No.1, (June 1998), pp.249-279, ISSN 0066-4294

Oliveira, A.B.; Gomes-Filho, E. (2009). Germinação e vigor de sorgo forrageiro sob estresse hídrico e salino. Revista Brasileira de Sementes, Vol. 31, No 3, (August 2009), pp.4856, ISSN 0101-3122

Papageorgiou, G.C.; Murata, N. (1995). The unusually strong stabilizing effects of glycine betaine on the structure and function of the oxygen-evolving Photosystem II complex. Photosynthesis Research, Vol.44, No.3, (September 1995), pp. 243- 252, ISSN 1573-5079,

Passioura, J.B. (2007). The drought environment: physical, biological and agricultural perspectives. Journal of Experimental Botany, Vol.58, No.2, (February 2007), pp. 113117, ISSN 1460-2431

Pérez-Pérez, J.G.; Robles, J.M.; Tovar, J.C. ; Botía, P. (2009). Response to drought and salt stress of lemon 'Fino 49' under field conditions: water relations, osmotic adjustment and gas exchange. Scientia Horticultura, Vol. 122, pp. 83-90.

Pinheiro, R.G.; Rao, M.V.; Palyath, G.; Murr, D.P.; Fletcher, R.A. (2001). Changes in the activities of antioxidant enzymes and their relationship to genetic and paclobutrazol - induced chilling tolerance of maize seedlings. Plant Physiology, Vol.114, No.2, (February 2001), pp.695-704, ISSN 1532-2548 
Rascio, A.; Platani, C.; Scalfati, G.; Tonti, A.; Di Fonzo, N. (1994). The accumulation of solutes and water binding strength in durum wheat. Physiologia Plantarum, Vol.90, No.4, (April 1994), pp.715-721, ISSN 0031-9317

Rodrigues, B.M.; Souza, B.D.; Nogueira, R.M.; Santos, M.G. (2010). Tolerance to water deficit in young trees of jackfruit and sugar apple. Revista Ciência Agronômica, Vol. 41, No. 2, pp. 245-252, (April/June 2010), ISSN 0045-6888

Shulaev, V.; Cortes, D.; Mittler, R. (2008). Metabolomics for plant stress response. Physiologia Plantarum, Vol.132, No.2, (January 2008), pp.1027-1040, ISSN 0031-9317

Silva, S.B.M.; Carvalho, N.M. (2008). Efeitos do estresse hídrico sobre o desempenho germinativo da semente de faveira (Clitoria fairchildiana R.A. Howard. FABACEAE) de diferentes tamanhos. Revista Brasileira de Sementes, Vol.30, No.1, (February 2008), pp.55-65, ISSN 0101-3122

Silva, M.A.; Silva, J.A.G.; Enciso, J.; Sharma, V.; Jifon, J. (2008). Yield components as indicators of drought tolerance of sugarcane. Scientia Agricola, Vol.65, No.6, (November/December 2008), pp.620-627, ISSN 0103-9016

Silva, E.C., Nogueira, R.J.M.C., Vale, F.H.A., Melo, N.F, Araújo, F.P. (2009). Water relations and organic solutes production in four umbu (Spondias tuberosa) tree genotypes under intermittent drought. Brazilian Journal of Plant Physiology, Vol.21, No.1, (January/March 2009), pp. 43-53, ISSN 1677-0420

Silva, E.C.; Silva, M.F.A.; Nogueira, R.J.M.C.; Albuquerque, M.B. (2010a). Growth evaluation and water relations of Erythrina velutina seedlings in response to drought stress. Brazilian Journal of Plant Physiology, Vol.22, No.4, (October/December 2010), pp. 225-233, ISSN 1677-0420

Silva, E.N.; Ribeiro, R.V.; Ferreira-Silva, S.L.; Viégas, R.A.; Silveira, J.A.G. (2010b). Comparative effects of salinity and water stress on photosynthesis, water relations and growth of Jatropha curcas plants. Journal of Arid Environments, Vol. 74, No. 10, (October 2010), pp. 1-8, ISSN 0140-1963

Silva, E.N.; Ferreira-Silva, S.L.; Viégas, R.A.; Silveira, J.A.G. (2010c). The role of organic and inorganic solutes in the osmotic adjustment of drought-stressed Jatropha curcas plants. Environmental and Experimental Botany, Vol. 69, No. 3, (December 2010), pp. 279-285, ISSN 0098-8472

Simão, E.A.; Takaki, M.B.; Cardoso, VJM. Germination response of Hylocereus setaceus (SalmDyck ex DC.) Ralf Bauer (Cactaceae) seeds to temperature and reduced water potentials. Brazilian Journal Biology, Vol. 70, No. 1, (February 2010), p. 135-144, ISSN 1519-6984

Smith, J.A.C.; Griffith, H. (1993). Water Deficits: Plant Responses from Cell to Community. Bios Scientific Publisher, ISBN 9-78-187274806-1, Oxford

Souza, R.P.; Machado, E.C.; Silva, J.A.B.; Lagôa, A.M.M.A.; Silveira, J.A.G. (2004). Photosynthetic gas exchange, chlorophyll fluorescence and some associated metabolic changes in cowpea (Vigna unguiculata) during water stress and recovery. Environmental and Experimental Botany, Vol. 51, No.1, (February 2004), pp. 45-56, ISSN 0098-8472

Souza, B.D.; Rodrigues, B.M.; Endres, L.; Santo, M.G. (2010). Ecophysiology parameters of four Brazilian Atlantic Forest species under shade and drought stress. Acta Physiologia Plantarum, Vol. 32, No. 4, (January 2010), pp. 729-737, ISSN 0137-5881 
Sucre, B.; Suárez, N. (2011). Effect of salinity and PEG-induced water stress on water status, gas exchange, solute accumulation, and leaf growth in Ipomoea pes-caprae. Environmental and Experimental Botany, Vol.70, No. 2, (February 2011), pp.192-203, ISSN 0098-8472

Suzuki, N.; Mittler, R. (2006). Reactive oxygen species and temperature stresses: a delicate balance between signaling and destruction. Physiologia Plantarum, Vol.126, No.1, (November 2005), pp.45-51, ISSN 0031-9317

Tabosa, J.N.; Reis, O.V.; Brito, A.R.M.B.; Monteiro, M.C.D.; Simplício, J.B.; Oliveira, J.A.C.; Silva, F.G.; Azevedo Neto, A.D.; Dias, F.M.; Lira, M.A.; Tavares Filho, J.J.; Nascimento, M.M.A.; Lima, L.E.; Carvalho, H.W.L.; Oliveira, L.R. (2002). Comportamento de cultivares de sorgo forrageiro em diferentes ambientes agroecológicos dos Estados de Pernambuco e Alagoas. Revista Brasileira de Milho e Sorgo, Vol.1, No.2, (May/ August 2002), pp.47-58, ISSN 1980-6477

Taiz, L.; Zeiger, E. (2009). Plant Physiology. Sinauer Associates, ISBN 978-0878938230, Sunderland

Tamura, T.; Hara, K.; Yamaguchi, Y.; Kolzumi, N.; Sano, H. (2003). Osmotic stress tolerance of transgenic tobacco expressing a gene encoding a membrane-located receptor-like protetn from tobacco plants. Plant Physiology, Vol.131, No.2, (February 2001), pp.454-462, ISSN 1532-2548

Tardieu, F. (2005). Plant tolerance to water deficit: physical limits and possibilities for progress. Comptes Rendus Geoscience, Vol.337, No.1, (January 2005), pp.57-67, ISSN 1631-0713

Yancy, P.H.; Clark, M.E.; Hand, S.C.; Bowlus, R.D.; Somero, G.N. (1982). Living with water stress: evolution of osmolyte systems. Science, Vol.21, No.4566, (September 1982), pp. 1214-1222, ISSN 1095-9203

Zhu, J.K.; Hasegawa, P.M.; Bressan, R.A. (1997). Molecular aspects of osmotic stress in plants. Critical Reviews in Plant Sciences, Vol.16, No.3, (February 1997), pp.253-277, ISSN 0735-2689 


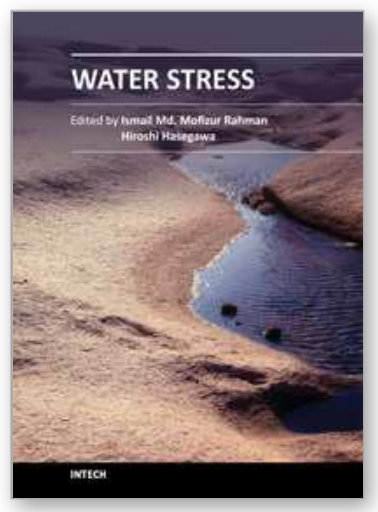

\author{
Water Stress \\ Edited by Prof. Ismail Md. Mofizur Rahman
}

ISBN 978-953-307-963-9

Hard cover, 300 pages

Publisher InTech

Published online 25, January, 2012

Published in print edition January, 2012

Plants experience water stress either when the water supply to their roots becomes limiting, or when the transpiration rate becomes intense. Water stress is primarily caused by a water deficit, such as a drought or high soil salinity. Each year, water stress on arable plants in different parts of the world disrupts agriculture and food supply with the final consequence: famine. Hence, the ability to withstand such stress is of immense economic importance. Plants try to adapt to the stress conditions with an array of biochemical and physiological interventions. This multi-authored edited compilation puts forth an all-inclusive picture on the mechanism and adaptation aspects of water stress. The prime objective of the book is to deliver a thoughtful mixture of viewpoints which will be useful to workers in all areas of plant sciences. We trust that the material covered in this book will be valuable in building strategies to counter water stress in plants.

\title{
How to reference
}

In order to correctly reference this scholarly work, feel free to copy and paste the following:

Alexandre Bosco de Oliveira, Nara Lídia Mendes Alencar and Enéas Gomes-Filho (2012). Physiological and Biochemical Responses of Semiarid Plants Subjected to Water Stress, Water Stress, Prof. Ismail Md. Mofizur Rahman (Ed.), ISBN: 978-953-307-963-9, InTech, Available from: http://www.intechopen.com/books/waterstress/physiological-and-biochemical-responses-of-semiarid-plants-subjected-to-water-stress

\section{INTECH}

open science | open minds

\author{
InTech Europe \\ University Campus STeP Ri \\ Slavka Krautzeka 83/A \\ 51000 Rijeka, Croatia \\ Phone: +385 (51) 770447 \\ Fax: +385 (51) 686166 \\ www.intechopen.com
}

\author{
InTech China \\ Unit 405, Office Block, Hotel Equatorial Shanghai \\ No.65, Yan An Road (West), Shanghai, 200040, China \\ 中国上海市延安西路65号上海国际贵都大饭店办公楼405单元 \\ Phone: +86-21-62489820 \\ Fax: $+86-21-62489821$
}


(C) 2012 The Author(s). Licensee IntechOpen. This is an open access article distributed under the terms of the Creative Commons Attribution 3.0 License, which permits unrestricted use, distribution, and reproduction in any medium, provided the original work is properly cited. 